\title{
Fourth International Grassland Congress
}

$\mathrm{T}$ HE paper-reading sessions of the fourth International Grassland Congress were held at Aberystwyth on July 14-18, under the presidency of Prof. R. G. Stapledon. A preliminary tour was arranged from Oxford through Leicestershire, the Cotswolds, Herefordshire and central Wales; a party of two hundred delegates left Oxford on July 10 and arrived in Aberystwyth on July 14. Delegates who participated in this tour had excellent opportunities of studying the modern developments in English grassland farming, such as the use and production of pedigree seed, artificial drying of grass, etc., and were therefore in a better position to appreciate the papers read afterwards by British specialists at the Aberystwyth meeting.

The numerous papers offered for presentation to the Congress were divided among plenary and sectional sessions. The plenary papers were divided into three groups, dealing with nutritional questions, herbage plant breeding and general grassland respectively. The sectional sessions, held on July 16 , covered the six subdivisions of grassland research, namely, (1) grassland ecology, (2) seed mixtures, (3) plant breeding and seed production, (4) manures and fertilizers, (5) nutritive value of pastures and fodder conservation, and (6) management, yields and economics of pastures.

The subject-matter of the papers read is perhaps best dealt with according to country; this Congress differed in scope from its three predecessors, held in Germany, Scandinavia and Switzerland respectively, as the $\mathbf{4 5 0}$ delegates came from thirty-seven countries in all parts of the world, and were therefore interested in more varied aspects of the grassland problem than at the earlier conferences.

The British papers were concerned chiefly with the breeding of pure-bred grasses and clovers (T. J. Jenkin and R. D. Williams, Aberystwyth), the production and marketing of seed of pure-bred strains (T. E. Miln, Warrington, and Gwilym Evans, Aberystwyth), the use of lime and phosphate in grassland improvement (J. A. Hanley, Newcastle, and R. G. Heddle and W. G. Ogg, Edinburgh and Aberdeen), the production and nutritive value of artificially dried grass (H. E. Woodman, Cambridge, and E. J. Roberts) and the economics of grassland improvement (John Orr, Manchester).

An important European paper was that delivered by A. I. Virtanen, Finland, on the associated growth of legumes and non-legumes; the old-established fact that non-legumes benefit by an association with legumes has been explained by recent work in his laboratory at Helsinki. Exact work with sterile culture technique has conclusively shown that nitrogenous compounds are excreted into the soil from legume nodules, and that this excretion commences immediately upon the formation of nodules. The excreted nitrogen compounds are products of nitrogen fixation and not decomposition products of proteins; the excretion products have been studied in an attempt to shed light on the mechanism of nitrogen fixation. The excretion is apparently an equilibrium reaction. Excretion of amino-acids has been demonstrated with all legumes so far examined (different species of clover, peas and lucerne). Application of nitrate appears to lower markedly the excretion.
A wide range of topics was covered by readers from other European countries. The Scandinavian countries have always been in the forefront as regards breeding of herbage plants; they were here represented by N. Sylvén and H. Osvald, Sweden, and O. Valle, Finland. C. K. van Daalen, Holland, also stressed the importance of using indigenous or purebred seed when sowing down pastures.

Papers on the grasslands of Hungary, read by K. T. Kolbai and J. von Piukovich, indicated the rapidly increasing interest in the subject in that country, where there are now three grassland unions with 60,000 farmer members. Another paper from the same country, by $\mathbf{N}$. von Bittera, dealt with the peculiar problems of applying fertilizers to arid grassland, a subject of direct importance to the delegates from North America, Africa and Australia.

The profitability of applying nitrogenous fertilizers was discussed by readers from Sweden, Holland and Germany, the conservation of grassland herbage in the form of silage by delegates from Great Britain, Switzerland and Germany, and the good effect of alpine pasturing upon the health of stock by V. Vezzani and E. Carbone of Italy. One of the leading grassland experts from Germany, E. Klapp of Bonn, compared the effects of mowing and grazing upon pastures in general and upon certain herbage grasses and legumes in particular.

The outstanding value of pastures in erosion control has been an important factor in the rapid growth of pasture research in the United States and Canada in recent years. It was therefore not surprising that these two countries should be well represented at the Congress ; the American delegation, under its chairman, P. V. Cardon, principal agronomist in charge, Division of Forage Crops and Diseases, Bureau of Plant Industry, U.S. Department of Agriculture, numbered fifty persons, the majority of whom were travelling in one party under the guidance of Dr. D. B. Johnstone-Wallace, Cornell University, on a tour of centres of grassland and scenic interest in Great Britain, Scandinavia, Germany, Austria, Switzerland and France.

Papers representing the current American outlook were read by three members of the U.S. Department of Agriculture, namely, P. V. Cardon (Bureau of Plant Industry), W. R. Chapline (U.S. Forest Service), and C. R. Enlow (Soil Conservation Service), who dealt respectively with the new herbage plant breed. ing programme, the revegetation and rehabilitation of the range lands of the western States and the value of pastures in erosion control. D. B. JohnstoneWallace described his experiments with wild white clover at Cornell University in New York State, which have been attracting so much attention in recent years among the pasture agronomists working in the more humid parts of the eastern United States.

L. E. Kirk discussed the herbage plant breeding problems of eastern and western Canada, while O. McConkey directed attention to the serious mineral deficiencies in the pastures of eastern Canada.

H. R. Marston presented in scientific terms the Australian sheep farmers' argument that "sown pastures ruin the wool" of the merino sheep. Improvement of the nutritional level of a pasture from 
one which has seriously handicapped production will certainly affect the quality (fineness) of the fleece, but this change may just as certainly be made, if need be, by the alteration of the type of sheep used for wool-growing on these areas. Small-framed, densely covered breeds of merinos which have been selected to produce fine wool when grazed on richer areas are well known.

E. Bruce Levy described the conversion of rain forest to grassland in New Zealand; the forests converted are mainly of two types: rain forest proper and sub-antarctic southern beech forest. The stages of the conversion to the famous pastures of New Zealand were described in full, particular credit being given to the pioneer back-country bush settlers. A similar topie was discussed by G. H. Holford, New Zealand, who illustrated his talk with a colour film.

The changing agricultural outlook in South Africa, resulting from the ravages of soil erosion, was described by the representative of the South African Department of Agriculture, J. W. Rowland. A reorientation of the principles of arid land farming must come about, governed by a full consideration of the land, in the light of the complex inter-relationship between the soil, the plant and the climate.

The Congress ended with a tour through Northumberland to Edinburgh, when a day was spent in the Central Highlands of Scotland and the Trossachs.

The report of the Fourth Congress, containing the full text of all papers read, together with their English and German abstracts, will be published in October or November of this year, price $£ 2$ per copy. A volume containing the abstracts only (in English and German) is now available, price 5s., and may be obtained from the joint Secretaries, Fourth International Grassland Congress, Aberystwyth.

At the general meeting of the International Grass. land Congress Association on July 16, Dr. D. S. Huizinga of the Netherlands repeated the invitation, already given at the Third Congress at Zürich, to hold the Fifth Congress in the Netherlands in 1940. The invitation was gratefully accepted, and Dr. Huizinga was elected president of the Fifth Congress The Association was invited by Count Teleki of Hungary to hold its sixth meeting in that country in 1943 .

\section{Geology of Jersey}

$\mathrm{T}$ HE claims of Jersey in the Channel Islands as a field of research for British geologists and as a most suitable locality for field classes for students has more than once been urged. The chief reason why Jersey is not more widely used for the latter purpose, in spite of its undoubted attractions, is the lack of a modern complete connected account of the geology of the island.

In September 1934, the Geological and Mineralogical Society of Brittany visited the island under the direction of A. J. Robinson and A. E. Mourant. The report of the excursion has recently been published as a memoir of the Society ${ }^{1}$, and should prove invaluable to geologists intending to visit Jersey. The work is in French ; but it is typical scientific French, and the writers clearly realized that many of its readers would be English-speaking. Probably for this reason, the work of those English geologists who established the succession and relationships of the rock groups of Jersey is barely mentioned. In justice to them, however, it should be stated that the relationships described by Wells and Wooldridge ${ }^{2}$ are accepted by the writers of the memoir, with one exception; they claim that no important break occurs between the St. Lo shales and the volcanic group.

A broad outline of the geology of Jersey is condensed into the first few pages, while the rest of the first part of the memoir is taken up by a detailed day-by-day account of the excursion. The memoir is, however, much more than a mere itinerary: it includes discussions of the many problems of age and field relations which still await complete solution. Thus the commonly accepted view that the lavas are of Pre-Cambrian age and probably to be correlated with the Uriconian volcanic rocks of Britain, is re-examined in the light of a careful comparison between the Jersey lavas and those of the mainland of Brittany, and in view of the claim strongly urged by M. Y. Milon, of the University of Rennes, that the lavas of Paimpol are of Carboniferous, not PreCambrian, age.
M. Milon himself contributes interesting "Notes and Observations on the Geology of Jersey and Armorica". In particular, the age and conditions of accumulation of the Rozel conglomerate group are discussed, and it is concluded that these rocks, so strikingly similar to the Permian breccio-conglomerates of eastern Devonshire, were deposited on the borders of a Permo-Triassic cuvette, under 'continental' conditions.

In addition to the solid geology, the Pleistocene deposits, the raised beaches and the caves are adequately described by M. A. Bigot in the second part of the memoir.

Although natural inland outcrops are few in Jersey, the island provides a magnificent series of coastal exposures in the cliffs and extensive wave-cut platforms. In the main, these exposures are not difficult of access; but the casual visitor is liable to disappointment unless the tides are studied and the routes so chosen as to take full advantage of the periods of low water. With commendable foresight, the authors recommend in the introduction that the conditions are most favourable during the period comprising the three days before new or full moon and the five days which follow. The authors are resident in Jersey, and their detailed local knowledge has ensured that in the course of the five journeys described the time would be used to the best advantage and the maximum of geology would be seen. Each route is clearly shown on a sketch-map, with localities numbered to correspond with the text. For those with more time at their disposal, additional excursions are suggested.

Among the nineteen figures included in the text are several geological sketch-maps on a generous scale, while a folding geological map on the scale of 1 : 50,000 and five plates are incorporated.

A. K. W.

1 "Contributions à l'étude géologique des Iles de la Manche et du Trégorrois." Mem. Soc. Géol. et Min. de Bretagne, 8 (1936). Obtainable from Prof. Y. Milon, Institut de Géologie, Rennes (30 francs), and the Museum, 9 Pier Road, Jersey (5s.).

${ }^{2}$ Proc. Geol. As8oc., 42, 78 (1931). 